\title{
K vývoji právního postavení sloužících v raném novověku
}

\author{
Ladislav Nekvapil
}

Východočeské muzeum v Pardubicich

Kontaktni e-mail:nekvapil@vcm.cz

\section{On the Development of the Legal Status of Servants in the Early Modern Period}

\begin{abstract}
:
This paper deals with the outline of the legal status of servants from the late Middle Ages up to the codification of civil law at the beginning of the 19th century. Labour law was not a simple matter during the Early Modern Era; it was a complex, multi-layered component of (primarily) the system of private law, and it operated and evolved on several different levels. In simple terms, Early Modern law pertaining to domestic service originated in a municipal legal framework or in legislation governing the institute of hereditary subjection. Both frameworks were codified during the 16th century; nevertheless, some areas of the law remained on the level of customary practice until the 18th century (e.g. in the case of members of the Estates serving as officials or employees of the nobility). The main purpose of this study is to summarize and evaluate the results of previous research focusing on the legal status of servants in the Lands of the Bohemian Crown. In a form of excursion the article also deals with the term of "compulsory service" with land nobility. In conclusion, the paper attempts to describe the analogous and different aspects of the development of the legal status of servants in the Central European area.
\end{abstract}

Keywords: servants; domestic service; Early Modern Era; labour law; wage labor

Klíčová slova: sloužící; čeled'; čelední služba; raný novověk; pracovní právo; námezdní práce

DOI: $10.14712 / 2464689 X .2020 .5$

Právní postavení sloužících či námezdně pracujících obecně a jeho vývoj v dějinách patř́ v rámci české historiografie $\mathrm{k}$ tématům, kterým doposud nebyla věnována dostatečná pozornost. Přitom se jedná o problematiku, která se dotýká značné části historické populace již od dob vrcholného středověku a která zároveň úzce souvisí s řadou dalších otázek; 
mezi ně lze řadit například podobu vzájemného soužití různých společenských vrstev, ${ }^{1}$ otázku terminologického a definičního vymezení některých zásadních pojmů běžně užívaných evropskou historiografií, ${ }^{2}$ nebo kontinuální implementaci konkrétních prvků raných feudálních pracovněprávních ustanovení do novějších normativních předpisů.

Hlubší zájem o téma právního postavení pracujících v období raného novověku se začíná v česky a německy mluvících zemích objevovat na konci 19. a s počátkem 20. století, kdy se autoři, často obdaření právním vzděláním, obracejí ke komparativnímu studiu právních norem, namísto doposud zpracovávaných obsáhlých chronologických soupisů a edic normativních pramenů. Jejich pozornost je přesto věnována době jim z časového hlediska nejbližší, tedy 19. a 20. století. Nicméně i tak se jedná o průkopnická díla, která pracují s velkými objemy často i marginálních pramenů a která tak v řadě prípadů dodnes představují důležité zdroje poznání právních poměrů sloužících a dalších námezdně pracujících skupin obyvatel od 16 . století. $^{3}$ Touto problematikou se také zabývali někteří další autoři v období 50. a 60. let v Československu, jejichž závěry však, jak ukážeme dále, do určité míry podléhaly dobovým konotacím.

Dosavadní studie věnované různým aspektům námezdní práce v raném novověku pojímají danou problematiku většinou příliš přímočaře či stručně, jelikož nevycházejí z širší komparativní analýzy dobových - zejména normativních - pramenů, která je v tomto případě nezbytná. ${ }^{4}$ Často jsou rovněž, i vzhledem k době svého vzniku, poznamenány

1 V této souvislosti zejména vymezení práv a povinností zaměstnanců a zaměstnavatelů, kteří se mohli rekrutovat z různých společenských vrstev (např. služba poddaného u měšt’ana či šlechtice, ale rovněž služba šlechtice u šlechtice jiného atd.).

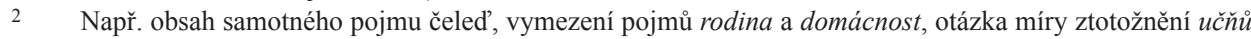
a tovaryšů s čeledí a jejich postavení v rámci řemeslnické domácnosti apod.

3 Pro české právní poměry zejména studie zabývající se vývojem jednotlivých edic čeledních řádů viz KREJČÍ, R. Snahy o reformu řádu čeledního v královstvi Českém. Sborník věd právnich a státních, 1913, roč. 13, s. 390-415; k situaci v českých zemích v 19. století viz PODLIPSKÝ, P. Zákonná ustanovení o čeledi platici v království Českém: stručný a populárni výklad řádu čeledního pro hlavni město Prahu, vydaného vyhláškou c. k. místodržitelství ze dne 21. srpna 1857 a řádu čeledního pro královstvi České, vydaného zák. ze dne 7. dubna 1866: k praktickému použití pro služebné pány i pro čeledíny v Praze i na venkově v záležitostech týkajicích se poměrů mezi pány a čelediny. Praha: Jaroslav Pospíšil, 1892; případně pojednání věnující se konkrétní problematice daného typu pracovní smlouvy v kontextu vývoje dalších druhů smluv v právním prostředí přelomu 19. a 20. století, s odkazy na tereziánské zákonodárství viz KRČMÁR̆, J. O smlouvě námezdni dle práva rakouského se zretelem ku právu řimskému. I., část úvodní. Praha: Bursík \& Kohout, 1902.

4 Nejstarší a zároveň nejobsáhlejší práci k právnímu postavení čeledi v rámci habsburské monarchie od doby středověku až do roku 1810, která je navíc postavena na dobré znalosti normativních pramenů, představuje bezpochyby spis MORGENSTERN, H. Gesindewesen und Gesinderecht in Österreich. Wien: Hölder, 1902. Zřejmě nejprrínosnější studií k danému tématu je pro české poměry URFUS, V. Právní postavení námezdních pracovníků u nás v 16. až 18. století. Právněhistorické studie, 1956, roč. 2, s. 198-249. Na jedné straně jde o pramenně nesmírně cennou analýzu pracovněprávních předpisů raného novověku, na druhou stranu zde autor na řadě míst inklinuje ke zjednodušeným závěrům vyvozeným na základě třebas jediného pramenného odkazu; rovněž přiliš nereflektuje necechovní městskou čeled' a učně, nevšímá si ani řady právních nařízení absolutistického státu 18. století, týkajících se zejména nezletilých dětí (především sirotků a dětí vojáků) ve vztahu k čelední službě apod. Novějším zpracováním pracovněprávní problematiky raného novověku, které je spíše znovuobjevením Urfusovy studie, z níž vychází, a nepřispívá tudíž k výraznému prohloubení poznatků, viz KOTOUS, J. Ke kořenům pracovního práva. Aplikované právo, 2004, č. 2, s. 43-57. Pracovněprávní problematika středověku a raného novověku se stala okrajovým tématem dalších prací věnujících se dějinám měst i venkova, z autorů stojí za zmínku zejména Zikmund Winter, 
přístupy marxistické historiografie v pojetí výrobních vztahů, přičemž nezřídka chápou námezdně pracující (vč. učňů a tovaryšů v městském prostředí) jako nutně vykořist'ovanou složku společnosti ze strany zaměstnavatelů. ${ }^{5} \mathrm{~S}$ tím ve starší domácí historiografii souvisí i časté pojetí čeledi coby (součásti) nejnižší společenské tř́idy, ${ }^{6}$ reprezentované městskou či venkovskou chudinou, což je z dnešního pohledu přístup značně zjednodušující. ${ }^{7}$

Při studiu právního postavení sloužících v období raného novověku je nutné kořeny pracovněprávních vztahů hledat již v období 13. a zejména pak 14. a 15. století, ${ }^{8}$ a to zejména $\mathrm{v}$ artikulích nově se formujících cechů, které představují jedny z mála dochovaných písemných pramenů obsahujících mimo jiné ustanovení o právech a povinnostech městských námezdních pracovníků, tedy speciálně těch cechovních, tzn. učňů a tovaryšů. V tomto období se totiž stále pohybujeme v okruhu feudálního obyčejového (zvykového) práva, jehož písemná kodifikace přichází nejdříve s první třetinou 16. století. Přesto ve zmíněných cechovních artikulích nalezneme několik důležitých pracovněprávních prvků, které

František Graus, Josef Janáček, Jiří Kejř (městské prostředí), Josef Kalousek, Václav Černý, Alois Míka, Josef Petráň, Arnošt Klíma, Kamil Krofta, Jaroslav Čechura (venkovské prostředí) ad. Citace konkrétních prací viz príslušné pasáže.

5 František Graus líčí stávky a sociální nepokoje v předhusitských městech jako „boje ,chudiny“ (mezi nimi i tovaryšů) s vydřiduchy“. Viz GRAUS, F. Chudina městská v době předhusitské. Praha: Melantrich, 1949, s. 54. „Početná je chudina, jejíž postavení se podobá skomírání. Postavení tzv. střední vrstvy drobných řemeslníků se neustále zhoršuje. Jako přízrak se před ní objevuje hrozba úplné pauperisace. Situace je bezvýchodná. Zbývala jediná cesta - revolucí otřást základy existujícího hospodářského a sociálního uspořádání společnosti.“Viz tamtéž, s. 131. Dále zejména JANÁČEK, J. Řemeslná výroba v českých městech v 16. století. Praha: ČSAV, 1961, s. 230 (tovaryš jako element třídního boje proti vykořist'ovatelům); JANÁČEK, J. Přehled vývoje řemeslné výroby v českých zemich za feudalismu. Praha: SPN, 1963, s. 87-90, 241-242 (vztah mistra ke členům řemeslnické dílny), s. 244 (tovaryšská otázka), s. 247 (tovaryšské cechy jako brzda třídního boje mezi tovaryši a mistry) ad. Značný vliv marxistické historiografie je patrný rovněž ve zmíněné studii $\mathrm{V}$. Urfuse.

6 Blíže viz MAUR, E. Čeled' a tovaryši v Čechách v soupisu podle víry z roku 1651. Historická demografie, 1999, č. 23, s. 85-134, zde s. 86-87.

7 Jiří Kejř zcela odmítá pro městské prostředí pokus části marxistické historiografie o začlenění stř̌edověkého měšt’anstva mezi tř́idy, brání se užívání tohoto pojmu a navrhuje kategorie „vrstva“ či „skupina“, viz KEJŘ, J. Vznik městského zrízení v českých zemích. Praha: Karolinum, 1998, s. 284. Se zařazením čeledi k městské chudině přišel jako první GRAUS, Chudina městská, s. 33-35, jehož přístup se stal inspirací pro další autory. Např. Valentin Urfus rovněž chápe námezdní pracovníky ve městech jako městskou chudinu neustále ohrožující v rámci „,rřídního“ boje městský patriciát, viz URFUS, c. d., s. 226. Stejně tak František Hoffmann v prvním vydání Českého města ve středověku (vyd. 1992) řadí k chudině velmi široké spektrum městského obyvatelstva vč. tovaryšů, čeledi, nádeníků, zbídačených řemeslníků ad. V druhém vydání knihy (2009) je autor v definování městské chudiny mnohem opatrnější, viz HOFFMANN, F. České město ve středověku. Praha: Panorama, 1992, s. 220-221; HOFFMANN, F. Středověké město v Čechách a na Moravě. Praha: Nakladatelství Lidové noviny, 2009, s. 328 a násl. Práce reprezentující pojetí čeledi (venkovské) coby nejnižší sociální vrstvy, jejíž šance na vzestup z této kategorie takřka neexistovala, viz GRAUS, F. Dějiny venkovského lidu v Čechách v době predhusitské. Praha: Státní nakladatelství politické literatury, 1957; MÍKA, A. Poddaný lid v Čechách v první polovině 16. století. Praha: Nakladatelství Československé akademie věd, 1960; PETRÁŇ, J. Poddaný lid v Čechách na prahu třicetileté války. Praha: Nakladatelství Československé akademie věd, 1964.

8 Za prvotní písemnou pracovněprávní úpravu jsou považována Břetislavova (Hnězdenská) dekreta z roku 1039, dalším významným dokumentem s již obsáhlou recepcí římského práva je Ius regale montanorum (1300), vzniklý v souvislosti s rozmachem hornictví na přelomu 13. a 14. století. Viz KOTOUS, Ke kořenům, s. 43-44. Ke zmíněným dokumentům blíže viz ADAMOVÁ, K. - SOUKUP, L. Prameny k dějinám práva v českých zemích. 2. upr. vyd. Plzeň: Vydavatelství a nakladatelství Aleš Čeněk, 2010, s. 19-20, 29-34. 
byly později zakomponovány do městského i obecného (šlechtického, zemského) práva. ${ }^{9}$ V tomto ohledu je nespornou výhodou pro badatele zabývajícího se českými právními dějinami skutečnost, že většina základních dokumentů z okruhu městského i šlechtického práva byla v minulosti edičně zpracována (snad jen s výjimkou cechovních artikulí), ${ }^{10}$ což i vzhledem k moderním digitalizačním projektům zpřístupňujícím zmíněné publikace $\mathrm{v}$ online podobě ${ }^{11}$ značně ulehčuje orientaci v dané problematice i samotný př́stup k těmto typům pramenů.

Cílem této studie není vypracování komplexního a detailního přehledu právního postavení námezdně pracujících, nýbrž zamyšlení nad některými terminologickými otázkami souvisejícími s čeledí a čelední službou, částečně pak také doplnění a revize některých poznatků starší historiografie, ${ }^{12}$ zejména pak bližší seznámení s prvotními kroky k právnímu vymezení sloužících v rámci kodifikací zvykového práva z 16. století na zemské i městské úrovni. Zde je totiž třeba hledat skutečný základ právního i terminologického vymezení sloužících, na kterém stavěli autoři právních norem a kodifikačních pokusů po zbytek raného novověku; pro městské prostředí lze v př́ípadě Koldínova zákoníku (1579), který představoval dovršení vývoje městského práva v Čechách, hovořit dokonce o nastavení neměnného stavu až do vydání Všeobecného občanského zákoníku (1811), ${ }^{13}$ snad jen s výjimkou některých speciálních předpisů, jako byly např́ílad nové josefínské právní normy vzniklé v souvislosti se zrušením nevolnictví v roce 1781, které se dotkly rovněž čeledi městské. ${ }^{14}$

9 „Základním systémem feudálního práva bylo jeho dělení na právo šlechtické - obecné či zemské - a práva zvláštní, která byla zemskému právu podřízena a nesměla mu odporovat. [...] Mezi nejdůležitější práva zvláštní pak patřilo právo městské, církevní, dále pak horní, viničné apod.“ Viz MALÝ, K. a kol. Dějiny českého a československého práva do roku 1945. Praha: Linde, 1997, s. 79.

10 Výběrem pro městské prostředí např. JIREČEK, J. - JIREČEK, H. (eds.). M. Brikcího z Licka Práva městská. Dle textu z r. 1536. Praha: Nákladem Právnické jednoty, 1880; JIREČEK, J. (ed.). Mag. Pauli Christiani a Koldin Jus municipale Regni Bohemiae (Codex juris Bohemici IV/3). Praha: F. Tempsky, 1876; Koldínova Práva městská nejnověji viz MALÝ, K. a kol. (eds.). Práva městská Království českého. Edice s komentářem. Praha: Karolinum, 2013; TOMEK, V. V. (ed.). Artikule cechů Pražských z 15. století (Archiv český 14). Praha: Domestikální fond království Českého, 1895. K zemskému právu viz např. JIREČEK, J. JIREČEK, H. (eds.). Zř́zení zemská Království českého XVI. věku. Praha: Všehrd, 1882; shodně pak jako JIREČEK, J. - JIREČEK, H. (eds.). Jura et constitutiones Regni Bohemiae saeculi XVI. (Codex juris Bohemici IV/1). Praha: Fr. Tempsky, 1882; Sněmy české od léta 1526 až po naši dobu. Díl I-XV. Praha, 1877-1917 (1945); JIREČEK, H. (ed.). Obnovené Právo a Zřrizeni Zemské dědičného království Českého 1627. Praha: F. Tempsky, 1888 ad. Základní přehled edičních počinů k dějinám práva viz MALÝ a kol. Déjiny českého a československého práva, s. 14-15.

11 K nejvýznamnějším online webovým databázím, které shromažd’ují materiály mj. k právním dějinám českých zemí období stř̌edověku a raného novověku (např. ediční řady Archiv český či Codex juris Bohemici) patří digitální úložiště provozované Centrem medievistických studií v Praze, viz Czech medieval sources online. [online]. Dostupné na: http://cms.flu.cas.cz/cz/badatele/sources-on-line.html. [cit. 11. 9. 2014]. Dalším projektem, který zpřístupňuje například edici Sněmy české od leta 1526 až na naši dobu je Digitální repozitář Poslanecké sněmovny Parlamentu České republiky, viz Digitální knihovna „České sněmy“. [online]. Dostupné na: http://www.psp.cz/eknih/snemy/index.htm. [cit. 11. 9. 2014].

12 Citováno výše.

13 MALÝ, K. Vývoj městského práva v Čechách (namísto úvodu). In: MALÝ a kol. (eds.). Práva městská, s. $11,18-19$.

14 Vydání čeledního řádu pro městskou čeled' 21. prosince 1782 (Stadtgesindeordnung in Böhmen, Mähren und Schlesien). Blíže viz KREJČÍ, c. d., s. 398, 401-402. 
Pokusíme se zde také podat stručný přehled vývoje čeledního práva v rámci středoevropského prostoru, přičemž si plně uvědomujeme rozdíly v právních systémech jednotlivých zemí. Proto se soustředíme především na společné kvalitativní znaky právní úpravy sloužících, které i přes zmíněné diference v normách dotčených zemí nalézáme. Poukážeme také na některá specifika námezdní práce, jako byla tzv. povinná či nucená služba, v Čechách oficiálně uzákoněná pouhých 26 let, od roku 1765 po zrušení nevolnictví v roce $1781,{ }^{15}$ což nic nemění na faktu, že ji pozemkové vrchnosti od poddaných vymáhaly de facto již od první třetiny 16 . století.

\section{Pojetí čeledi v normativních pramenech raného novověku}

Právní úprava postavení sloužících nebo chceme-li čeledi v období 16. až 18. století představovala majoritní část tehdejšího pracovního práva. To se přitom intenzivněji vyvíjelo od vrcholného středověku, pro středoevropský prostor je jakýmsi základem další evoluce většiny právních systémů, včetně pracovního práva, především německé Saské zrcadlo (Sachsenspiegel) z první třetiny 13. století. ${ }^{16}$ Tehdejší specifikace práv a povinností námezdně pracujících osob a jejich zaměstnavatelů byla velice strohá a kusá, nicméně již v této době byl položen základ právního vztahu mezi zaměstnavatelem a sloužícím, kdy pán po dobu vyplácení mzdy odpovídal za svého sluhu dle podmínek smlouvy, jejímž uzavřením se zakládal podřizený vztah čeledi vi̊či zaměstnavateli. Sloužící přitom ručil za veškeré škody způsobené pánovi, včetně předčasného ukončení pracovního poměru a případného zběhnutí. Na druhou stranu měl zaměstnavatel povinnost řádně vyplácet sloužícímu mzdu. ${ }^{17}$

K prvním významnějším kodifikacím „čeledního práva“, jak je běžně označováno právo sloužících v německé historiografii (Gesinderecht), docházelo až v průběhu 16. století, s čímž úzce souvisí i vytvoření přesnějšího členění námezdně pracujících osob na čeled, tedy osoby v dlouhodobém námezdním poměru, podléhající disciplinární pravomoci zaměstnavatele a integrované do jeho domácnosti, a nádeníky, zaměstnávané na krátkodobou práci či jednorázové úkoly, kteří nepodléhali disciplinární pravomoci pána. ${ }^{18}$ Zatímco první skupina je typická pro venkovské zemědělské hospodářství a také městské domácnosti, př́padně jako nekvalifikovaná pracovní síla v cechovním řemeslnickém prostředí, druhá kategorie je spojena především s většími městy a také sezónními zemědělskými pracemi, velmi často právě v okolí těchto měst. ${ }^{19} \mathrm{~V}$ českém právním systému je zřetelné oddělení obou zmíněných typů námezdních pracovníků od poloviny 16. století, přesněji řečeno v čeledním řádu z roku 1547, který na zemské úrovni definoval práva a povinnosti zaměstnanců i zaměstnavatelů, navíc stanovoval mzdové tarify na úrovni jednotlivých

15 Patent Josefa II. o zrušení nevolnictví z 1. listopadu 1781.

16 Kromě značného vlivu zvykového práva byl základem trestního práva polských měst mj. právě německý Sachsenspiegel. Viz KUKLO, C. - KAMECKA, M. Polští sloužící v právní praxi: pravidla a jejich porušování (konec 15. - počátek 19. století). Historická demografie, 2003, č. 27, s. 123-132, zde s. 123.

17 LENDEROVÁ, M. a kol. Žena v českých zemích od středověku do 20. století. Praha: Nakladatelství Lidové noviny, 2009, s. 368.

18 URFUS, c. d., s. 202-204.

19 Města potřebovala poddané (včetně zběhlých) jako nekvalifikované pracovní síly k sezónním pracím, na vinicích, stavbách, v hornictví, hutnictví, i $\mathrm{k}$ př́ležitostným službám, přičemž o jejich původ se příliš nezajímala. PETRÁŇ, c. d., s. 198. 
krajů především pro nádeníky. ${ }^{20}$ Co se týče terminologie, hovořil zmíněný čelední řád o „čeledi všelijaké př́stavní a nádenní“, dále o usnesení „strany čeledi i jiných všech oukolníkův aneb nádenníků obojího pohlaví, jakéžkoli povahy [...]“, z čehož významová rozdílnost pojmů jasně vyplývá. Toto pojetí, jak uvedeme dále v části věnované zemskému právu, od 60. let 16. století převzalo i zemské zřízení, v rámci něhož, integrováno také do Obnoveného zřízení zemského z roku 1627, zůstalo v téměř intaktní podobě až do poloviny 19. století. Tím však stratifikace sloužících v českém právním systému odbyta nebyla. Již vydání Vladislavského zřízení zemského z roku 1500 se v samostatných ustanoveních dotýkalo tzv. služebniki̊, jejichž status se od postavení ostatní čeledi lišil. Jednalo se totiž o sloužící v úřednické nebo osobní službě vrchnosti, často stavovského původu, jejichž právní postavení bylo až do 18. století z velké části ponecháno v okruhu zvykového práva (,páni jich se k nim zachovaje, jakož jest od starodávna bývalo“). ${ }^{21} \mathrm{~V}$ Obnoveném zřízení zemském se v této souvislosti píše o úrednících, služebnících a lidech poddaných, ${ }^{22}$ v pramenech 18. století už nalezneme jako analogii k termínům úředník a služebník pojmy hospodářský a domovní oficiant. ${ }^{23}$

Výslovné vymezení obsahu pojmů čeled' a oficiant se však v českém právu objevuje až po polovině 18 . století, a to v tereziánském čeledním řádu pro Čechy (1765), který obsahově vychází z obdobných norem pro Slezsko (1752) a pro Moravu (1753). Zde jsou za čeled' či čeládku považovány ty osoby, které u nejrůznějších typů zaměstnavatelů ,pod stálou mzdou a na chlebu stojejí“ (hlava I.). Tato značně široká definice má, i podle citované normy, pojmout rovněž nádeníky a oficianty. Oficiantům je pak věnována samostatná část čeledního řádu (hlava VIII.), která vymezení této skupiny sloužících více zpřesňuje.

Tím jsme v podstatě otevřeli terminologickou otázku vymezení sloužících v českém právním systému raného novověku. ${ }^{24}$ Přes veškerou pestrost, se kterou se v pramenech setkáváme, lze situaci v českém právu hodnotit jako vcelku jasnou a přehlednou. K označení městských a venkovských sloužících v dlouhodobém pracovním poměru se od 16 . století v zemském (analogicky i vrchnostenském) právu setkáváme s pojmy čeled' nebo čeládka, někdy s adjektivem př́stavní či služebná, u námezdních pracovníků v krátkodobém poměru s termíny nádeník nebo oukolník. Vymezení služebníků potažmo oficiantů jsme přiblížili výše. V městském právu se pro nekvalifikované sloužící užívalo běžně pojmů pacholek a děvečka, nebo souhrnně čeled', v př́padě kvalifikovaných cechovních pracovních sil se jednalo o učně (učedlníky, robence) a tovaryše (knechty). Někdy se obě kategorie označovaly i zmíněným pojmem pacholek, ačkoliv většinou nebylo možné určit, zda se jedná o učně či tovaryše. V německém právu se v raném novověku můžeme setkat v podstatě se dvěma základními termíny pro pojmenování čeledi. Jedná se o pojmy (das) Gesinde a Dienstbote, které byly ve starším období významově v podstatě shodné, k jejich postup-

20 Artikulové o čeledi léta 1547. In: Sněmy české od léta 1526 až po naši dobu. Díl II, 1546-1557. Praha, 1880 , č. 170 .

21 Viz Vladislavské zř́zení zemské, redakce z let 1549 a 1564. In: JIREČEK, J. - JIREČEK, H. (eds.). Zřizení zemská, s. 380, 676.

22 JIREČEK (ed.), Obnovené Právo, s. 470, článek Q.28.

23 Národní archiv v Praze, Sbírka patentů, inv. č. 1690, Nový čelední řád pro Království české, 25. ledna 1765. Zde hlava VIII.

24 Terminologickým vymezením námezdně pracujících osob v tuzemském právu se zabýval např. URFUS, c. d., s. 203 . 
nému oddalování docházelo až od 19. století, kdy Dienstbote začal označovat pouze sloužící v domácnostech (především městských), zatímco pojem Gesinde reprezentoval široké spektrum sloužících vykonávajících různé činnosti. ${ }^{25}$ Existují však i čelední normy, které obsahují přesné vymezení pojmu čeled, jelikož vyjmenovávají konkrétní profese konané sloužícími; takovým normativem je například čelední řád pro Dolní Rakousy z roku 1688 (§ 2) nebo řád pro slezskou Vratislav z roku 1640, který zmiňuje všechna zaměstnání, která děvečky zastávaly. ${ }^{26}$ Nutno podotknout, že výrazně složitější než identifikace jednotlivých kategorií osob sloužících v rámci pramenů právní povahy bývá rozklíčování významu pracovních pozic či pracovního zařazení čeledi v pramenech evidenčních, ${ }^{27}$ což ovšem není předmětem tohoto přehledu.

Velice důležitou otázkou, na kterou nám mohou raně novověké právní prameny dát uspokojivou odpověd', je integrace sloužících do rodiny zaměstnavatele. Problém, který je po desetiletí diskutován i s ohledem na historiografický koncept celého domu v pojetí rakouského historika sociálních dějin Otto Brunnera, ${ }^{28}$ vidí soukromoprávní, pracovněprávní i formující se občanskoprávní normy 16. až 18. století vcelku jasně. V rámci českého pracovního práva sice nacházíme jen nepřímé „důkazy“ hovořící pro tvrzení, že čeled' se stávala po dobu služby neoddělitelnou součástí pánovy rodiny, právo německé však tento princip př́mo potvrzuje, přičemž není třeba pochybovat o tom, že tyto základní předpoklady čelední služby popsané v německém prostředí platily i v tuzemských poměrech. ${ }^{29}$

V této souvislosti zde zmíníme naučnou knihu spadající do žánru moralistní literatury, představitele německé Hausväterliteratur, ${ }^{30}$ vydanou poprvé nejspíš v roce 1564 v Lipsku, jejímž autorem je drážd'anský kazatel Peter Glaser, spis s př́iznačným názvem Gesind Teufel, ${ }^{31}$ který v roce 1586 v českém překladu vydal Daniel Adam z Veleslavína. Autor ve čtvrté kapitole knihy stran integrace sloužících do rodiny pána uvádí následující: „V čtvrtém přikázání svým Pán Bůh přikazuje: cti otce svého i matku svou, at’ se prodlouží dnové tvoji na zemi, kterouž Hospodin Bůh tvůj dá tobě. Jménem pak otce a matky míní se netoliko přirození tělesní rodičové, ale i všeliká světská vrchnost, i páni a hospodářové své čeládky se rozumějí a obsahují.“32

25 KÄHLER, W. Gesindewesen und Gesinderecht in Deutschland. Jena: Fischer, 1896, s. 1.

26 Blíže viz MORGENSTERN, c. d., s. 17-18.

27 K terminologii sloužících v českých raně novověkých pramenech pro výzkum sociálních dějin zejména MAUR, c. d., s. 85-135.

28 BRUNER, O. Das ,ganze Haus“ in der alteuropäischen „Ökonomik“. In: BRUNER, O. Neue Wege der Verfassungs- und Sozialgeschichte. Göttingen: Vandenhoeck \& Rupprecht, 1968, s. 103-127.

29 Problematiku Hausväterliteratur, dobových moralistních spisů a traktátů týkajících se organizace domu a postavení čeledi v něm pro německé prostředí vcelku vyčerpávajícím způsobem přiblížila DÜRR, R. Mägde in der Stadt. Das Beispiel Schwäbisch Hall in der Frühen Neuzeit. Frankfurt am Main - New York: Campus-Verl., 1995, s. 54-108.

30 Základní př́ručka k tématu Hausväterliteratur, která mj. shrnuje roli tohoto literárního žánru v dobovém nazírání tzv. „učení o domu“ a praktickém vzdělávání hospodářů viz HOFFMANN, J. Die „Hausväterliteratur “ und die „Predigten über den christlichen Hausstand“. Lehre vom Hause und Bildung für das häusliche Leben im 16., 17. und 18. Jahrhundert. Weinheim: J. Beltz, 1959.

31 GLASER, P. Gesind Teufel. Darin acht stueck gehandelt werden von des Gesindes vntrew welche im nachfolgenden blat verzeichnet. Leipzig, 1564.

32 [z VELESLAVÍNA, D. A. / GLASER, P.]. Čelednj Wůdce, čili upř́mná a spasitedlná rada wšem we službě stogjcjm aneb do služby se chystagjcjm. WOTÝPKA, J. (ed.). 3. vyd. Praha: Anna owdowělá Špinková, 
Právní přináležitost čeledi k rodině zaměstnavatele pak potvrzuje rovněž o dvě staletí mladší kodifikace bavorského občanského práva, Codex Maximilianeus Bavaricus Civilis z roku 1756, který ve čtvrté kapitole první části $(\S 1)$ uvádí: „Die Familie ist eine Versammlung, deren unter einem Gemeinschaftlichen Haus=Vater beysammen lebender Personen, [...] und begreift mithin nicht nur Eheleut, Kinder und Eltern, sondern auch Dienstboten $[\ldots]$ in sich. "33

Koneckonců formulaci osvětlující vztah čeledi k hospodáři, resp. přednostovi domácnosti, obsahovala i většina kodifikačních pokusů občanského práva tereziánské éry, a to $\mathrm{v}$ duchu stoletími ověřené praxe, kdy jedním z nejdůležitějších znaků čeledního poměru byl kromě uzavřeného smluvního svazku také vstup sloužícího do domácnosti zaměstnavatele (Horten, Martini). ${ }^{34}$

Čeled' tedy v raném novověku optikou dobových právních norem nepochybně náležela do okruhu pánovy rodiny vedle jeho dětí, se kterými sice byla po dobu služby na shodné úrovni sociální (hospodáŕ za sloužící jednal a zastupoval je u soudu), mohla, ale nemusela být na stejné úrovni po stránce emoční, avšak rozhodně nebyla z hlediska právního, jelikož nedisponovala vưči hlavě rodiny, resp. zaměstnavateli dědickým právem.

V rámci právního postavení čeledi v raném novověku se zajímavou otázkou zabývala Renate Dürr, která sledovala genderové aspekty vlivu právních norem na mužskou a ženskou část populace. Autorka tvrdí, že ačkoliv byly právní normy koncipovány pro obě pohlaví bez rozdílu, reálně z různých důvodů silněji dopadaly na ženy. Dokládá to například zmíněnou německou Hausväterliteratur, ve které je mnohem větší pozornost věnována povinnostem děveček, na něž jsou také výrazně více než na pacholky směřovány různé urážlivé letáky, obviňující je z hanebného chování. Rovněž okruh jejich prací je mnohem širší než u mužských sloužících, jejichž činnosti nejsou nikde blíže specifikovány. ${ }^{35}$

\section{Mezi zvykovým a kodifikovaným právem}

České „čelední právo“ období raného novověku je pojato ve čtyřech typech právních pramenů z hlediska provenienčního. Jedná se o právo městské, zemské (ve smyslu ,zemsko-stavovském“), státní policejní předpisy a právo vrchnostenské. Všechny zmíněné typy zákonodárství prodělaly od 16. do konce 18., resp. počátku 19. století ve vztahu k právní úpravě sloužících výrazný vývoj a ušly dlouhou cestu vedoucí od zvykového práva, přes kodifikace zemských stavů a policejní předpisy absolutistického státu, až k uzákonění civilních, či chceme-li občanských práv na všeobecné státní úrovni.

Městské právo zůstávalo do druhé poloviny 16. století v rovině obyčejů, jeho kodifikace prostřednictvím Koldínova zákoníku z roku 1579 však vytvořila velice stabilní a neměnné

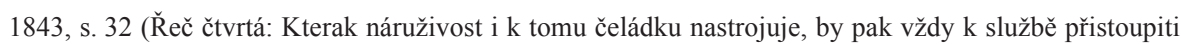
musila, aby času svého nedosluhovala). Blíže k překladu viz KOTOUS, J. „Čelední d'ábel“. Rukovět' námezdně pracujících z XVI. století. Právněhistorické studie, 2009, roč. 40, s. 411-424.

33 Citováno dle SCHRÖDER, R. Gesinderecht im 18. Jahrhundert. In: FRÜHSORGE, G. et al. (eds.). Gesinde im 18. Jahrhundert. Hamburg: Meiner, 1995, s. 13-40, zde s. 16.

34 URFUS, c. d., s. 244-246.

35 DÜRR, R. „Der Dienstbothe ist kein Tagelöhner...“. Zum Gesinderecht (16. bis 19. Jahrhundert). In: GERHARD, U. (ed.). Frauen in der Geschichte des Rechts: Von der Frühen Neuzeit bis zur Gegenwart. München: Beck, 1997, s. 115-139, zde s. 118-119. Autorka s tímto př́stupem pracuje i v monografii věnované ženským sloužícím v německém městě Schwäbisch Hall, viz DÜRR, Mägde in der Stadt. 
právní prostředí, které přežilo až do uzákonění občanských práv v roce $1811 .{ }^{36}$ Koldínův zákoník však z hlediska pracovního práva českých měst tvořil jen jistý obecný základ dotýkající se především nekvalifikovaných pracovníků, osudy těch specializovaných, které představovali zejména učni a tovaryši, pak upravovaly speciální předpisy cechovních organizací, tzv. cechovní statuta.

Zemsko-stavovská část právního řádu, kodifikovaná již v roce 1500 Vladislavským zemským zř́zením, obsahovala ve své původní podobě úpravu námezdní práce jen velmi okrajově a většina ustanovení stran čeledi zůstávala bud' v rovině zvykového práva, nebo v nálezech zemských soudů a usneseních zemských stavů. Ke vcelku komplexní implementaci práva sloužících do zemského zřízení došlo až v jeho poslední předbělohorské redakci z roku 1564. Do ní se totiž promítl jeden velmi důležitý dokument stojící na pomezí zemsko-stavovského a policejního předpisu, a sice čelední řád z roku 1547 vydaný na základě dohody zemských stavů s přihlédnutím ke specifickým potřebám jednotlivých krajů (zejména ve vztahu ke mzdovým taxám). ${ }^{37}$ Tato norma byla včleněna jako jeden ze článků - konkrétně M. 34 - do zmíněného vydání zemského zřízení (1564), odkud byla přenesena i do Obnoveného zřízení zemského z roku 1627 (zejména články se signaturou Q), platného coby ústavní zákon jedné ze zemí habsburského soustátí formovaného na nových základech v podstatě až do poloviny 19. století.

V rámci tohoto státního útvaru pak vydával panovník pro jednotlivé země policejní předpisy, které se mj. týkaly rovněž čeledi a čelední služby. Zcela zásadní byl především tereziánský čelední řád pro Čechy z roku 1765, ${ }^{38}$ navazující, jak jsme již uvedli, na analogické normy pro Slezsko $(1752)^{39}$ a Moravu (1753), ${ }^{40}$ který svou komplexností a restriktivním charakterem definoval čelední právo v duchu vrcholného nevolnictví, když dával v podstatě neomezenou moc nad sloužícími do rukou vrchností, především v případě venkovské čeledi. Další čelední řády byly vydány již za jiné situace, a sice rok po zrušení nevolnictví Josefem II., prričemž zcela poprvé zvlášt' upravovaly poměry v městském a venkovském prostředí. ${ }^{41}$ Tyto dokumenty z roku 1782 byly sice produktem osvícenských reforem, na druhou stranu způsobovaly jistou disproporci v právním postavení městské a venkovské čeledi, kdy pro vesnické sloužící se oproti době tereziánské, až na lepší specifikaci některých ustanovení, nic výrazně neměnilo. Oba jmenované čelední řády ovšem

36 Myšlenkové zdroje Koldínových Městských práv, která čerpala z práva římského, zemského, kanonického, horního i ze staršího práva pražského, podrobně rozebírá ŠTĚPÁN, J. Studie o kompilační povaze Koldinových Práv městských (Práce ze semináře českých právních dějin na Právnické fakultě Karlovy university v Praze, 26). Praha: Jan Kapras, 1940.

37 Edičně zpřístupněn in Sněmy české od léta 1526 až po naši dobu. II, 1546-1557. Praha, 1880, č. 170. Originální tisky uloženy v Národním archivu v Praze, fond Česká dvorská kancelár.

38 Národní archiv v Praze, Sbírka patentů, inv. č. 1690, Nový čelední řád pro Království české, 25. ledna 1765.

39 Blíže viz MORGENSTERN, c. d., s. 15.

40 Národní archiv v Praze, Sbírka patentů, inv. č. 1458, Dienstbothenordnung für das Marggrafthum Mähren, 12. květen 1753.

41 Edičně zpř́stupněny in Gesindordnung für das Landgesind in Böhmen, Mähren und Schlesien vom 30. September 1782. In: Handbuch aller unter der Regierung des Kaisers Joseph des II. für die K. K. Erbländer ergangenen Verordnungen und Gesetze. Erster Band, 1780-1784. Wien, 1785, s. 85-99, Nr. VI.; Ordnung für das Stadtgesind in Böhmen, Mähren und Schlesien vom 1. Dezember 1782. In: Handbuch aller unter der Regierung des Kaisers Joseph des II. für die K. K. Erbländer ergangenen Verordnungen und Gesetze. Erster Band, 1780-1784. Wien, 1785, s. 210-224, Nr. XXV. 
zůstávaly v platnosti až do 50. let 19. století, tedy do konstituování živnostenské legislativy.

Absolutistický stát však musel po stránce právní reagovat na zcela novou skupinu námezdních pracovníků, která se začala v českých zemích formovat od přelomu 17. a 18. století, a sice manufakturní dělnictvo. Ještě v první polovině 18. století upravovaly práci v manufakturách předpisy a zásady nádenické práce. První speciální normy pro manufaktury vznikaly od poloviny 18 . století, přičemž právní poměry manufakturních dělníků byly odlišné od čeledních i cechovních úprav. ${ }^{42}$

Vznikem manufakturní práce $\mathrm{v}$ podstatě skončilo období všeobecné právní úpravy námezdních poměrů v duchu čeledních předpisů, jelikož bylo nutné konfigurovat tři samostatné právní okruhy námezdní práce, a sice 1) /původní/ čelední námezdní poměry, které zahrnovaly především pracovníky v zemědělské výrobě a osobní službě (úprava prostřednictvím čeledních řádů), 2) řemeslnicko-živnostenské námezdní poměry upravené cechovními předpisy, a samostatně upravené 3) průmyslové námezdní poměry. ${ }^{43}$

Rudolf Krejčí ve své práci z roku 1913 věnované reformě českých čeledních řádů uvádí „hlavní zásady úpravy čeledního poměru v českém právu“ od středověku do vydání Obnoveného zřízení zemského (1627) následovně: 1) služební poměr mezi čeledí a hospodářem se upravuje čelední smlouvou, jejíž podstatný obsah se řídí místní zvyklostí a povahou věci; 2) čeledín nesmí být přijat do služby bez „,fedrovního listu“ nebo „propouštěcího listu“; 3) hospodář má čeledínovi vydat fedrovní list a zachování; 4) čeled' je povinna zachovat pracovní dobu (dosloužit); 5) zběhlá čeled' je potrestána, nikdo ji nesmí přechovávat. ${ }^{44}$ Tento značně zjednodušený pohled na celou záležitost vychází nepochybně z povrchní znalosti dobových pramenů k dané problematice, jelikož problém je značně složitější a mnohovrstevnatější, než autor naznačil. Jistě by se slušelo připojit i další rysy čelední služby, které vyplývají z rozboru právních pramenů různé provenience, přičemž jedním z těch nejvýraznějších, který byl od 16. století součástí vrchnostenské legislativy a v rámci tereziánských policejních nařízení po polovině 18 . století přímo uzákoněn, byl institut povinné (či nucené) čelední služby.

\section{EXKURZ: Nucená služba jako výsadní právo vrchnosti}

Nucená neboli povinná služba (Zwangdienst, Gesindezwangdienst), jak ji označuje německá historiografie, se dotýkala v podstatě výhradně venkovského prostoru ${ }^{45}$ a vycházela z tradičního práva pozemkových vrchností na neomezené nakládání se svými poddanými. Její potřeba se projevovala již od 16. století a byla spojena s rozvojem panského režijního hospodaření, které bylo závislé na přísunu značného množství levné pracovní síly pro zabezpečení fungování vrchnostenských podniků, především poplužních dvorů. ${ }^{46}$ Původně

42 URFUS, c. d., s. 248. K problematice manufakturní výroby v Čechách viz KLÍMA, A. Manufakturní obdobi v Čechách. Praha: ČSAV, 1955. Autor vydal na dané téma celou řadu studií v zahraničních vědeckých periodikách, tyto práce jsou méně zatíženy marxistickými konotacemi, viz zejm. KLÍMA, A. Industrial Development in Bohemia 1648-1781. Past and Present, 1957, Vol. 11, No. 1, s. 87-99 ad.

43 URFUS, c. d., s. 249.

44 KREJČ́, c. d., s. 395-396.

45 MORGENSTERN, c. d., s. 42-43.

46 VANĚČEK, V. Selské poddanství ve starém českém právu. Nástin právního vývoje stol. 12.-16. Český lid, 1948, roč. 35, č. 7/8, s. 149-152, zde s. 152; PETRÁŇ, c. d., s. 85. 
se dotýkala zřejmě výhradně sirotků, kteří byli na základě každoročního „stavění“ posíláni do služby, později - se zvyšující se aktivitou vrchnostenských podniků - byla rozšířena na všechny poddanské děti. Jeden z prvních náznaků „všeobecné“ povinné panské čelední služby nacházíme již v pernštejnské hospodářské instrukci vydané okolo roku 1525 pro panství Potštejn a Litice. Zde se v článku 23 píše, že „selští synové kteříž by na panství byli a při otcích svých živnosti nehleděli, ty na zámek za holomky aneb k jiné práci, k čemuž by jse který trefiti mohl, obracej, a služba necht’ jse jim též platí, jako jiným“. ${ }^{47}$ Již Vladislavské zemské zřízení (v pozdějších redakcích) nepř́ímo přiznávalo vrchnostem téměř neomezené právo užívat dětí svých poddaných $\mathrm{k}$ vlastním službám. ${ }^{48}$

Ačkoliv existují doklady o nucené službě již z éry předbělohorské, jak jsme naznačili výše, začíná se tato praxe v českých, rakouských i německých zemích více uplatňovat zřejmě až po třicetileté válce. ${ }^{49}$ Jako př́klad absence obecné nucené služby můžeme uvést zjištění Josefa Pekaře pro panství Kost v 17. století: „Na Kostecku také není zpráv o nucené službě všech poddanských dorostlých dětí ve dvorech panských po určitou dobu nebo o výplatě z ní. Mám za to, že tu ke službě vybíráni byli po starém obyčeji sirotci. A to ovšem za normální mzdu jako jinde. " ${ }^{50}$ Velmi zajímavými dokumenty jsou v tomto kontextu instrukce a řády pro dolnorakouská a moravská liechtensteinská panství z první půle 17. století. V policejním řádu Gundakera z Liechtensteina z roku 1601 (revidovaný a doplněný asi v roce 1637) pro panství Wilfersdorf v Dolních Rakousech se ani v rámci článků týkajících se právního postavení sirotků nesetkáváme se zmínkou o panské službě, nýbrž pouze s možností služby práceschopných osiřelých dětí, které nemohou být přijaty svými př́ibuznými, u cizích sedláků. Délka takové služby měla být jeden rok, přičemž po následném stavění doslouživších sirotků před vrchnost, kde jim měla být také ze strany zaměstnavatele vyplacena vysloužená mzda, mohl být čelední poměr prodloužen na další rok, př́ipadně měl být sirotek umístěn do služby $\mathrm{k}$ jinému hospodáři. ${ }^{51}$ Tyto zásady pak byly rozpracovány do samostatného sirotčiho řádu (Waisenordnung) pro stejné panství okolo roku 1615. Ten obsahoval celkem 25 ustanovení včetně článku popisujícího průběh sirotčích stavuňků. 52

47 KALOUSEK, J. (ed.). Řády selské a instrukce hospodářské (Archiv český 22: 1350-1626). Praha: Domestikální fond království Českého, 1905, s. 60, č. 46; ČERNÝ, V. Hospodářské instrukce. Přehled zemědělských dějin v době patrimonijního velkostatku v XV.-XIX. století. Praha: Československá akademie zemědělská, 1930, s. 96.

48 KROFTA, K. Dějiny selského stavu. 2. vyd. Praha: Jan Laichter, 1949, s. 107.

49 KÄHLER, $c$. d., s. 3-4. Instrukce pro česká komorní panství z roku 1604 hovořila pouze o sirotčí službě, zatímco její nová redakce z roku 1652 již obsahovala formulaci o povinných čeledních letech ,přístavní čeládky“، která se rekrutuje z poddaných i sirotků. Blíže MAUR, E. Český komorní velkostatekv 17. století: př́spěvek k otázce ,druhého nevolnictvi“ “v českých zemích. Praha: Univerzita Karlova, 1976, s. 122. V druhé polovině 17. století už i česká komora považovala tuto praxi za zcela samozřejmou. KROFTA, $c$. $d$., s. 201-203.

50 PEKAŘ, J. Kniha o kosti. Kus české historie. Díl druhý. 2. vyd. Praha: Melantrich, 1935, s. 111.

51 Policeyordnung Hartmanns II. von Liechtenstein für die Untertanen der Herrschaft Wilersdorf in der Fassung seines Sohnes Gundaker aus dem Jahre 1601 mit Änderungen und Ergänzungen bis etwa 1637; článek 46. Wie es der waisen halben gehallten soll werden. In: WINKELBAUER, T. Gundaker von Liechtenstein als Grundherr in Niederösterreich und Mähren. Wien - Köln - Weimar: Böhlau, 2008, s. 123-164, č. 2 , zde s. 150 .

52 Waisenordnung der Herrschaft Wilfersdorf (um 1615, in der vorliegenden Fassung um 1636). In: Tamtéž, s. $377-382$, č. 49 . 
Vrat'me se však k nucené službě po třicetileté válce a její - ne vždy pozitivní - reflexi dobovými prameny. Tu představuje kupř́ikladu i stížnost poddaných černínského panství Kysíbl císaři z roku 1669, která se v jednom z článků poukazujících na sociální útisk ze strany vrchnosti dotýkala právě nucené služby. Poddaným se nelíbilo, že jejich děti musí chodit do dvorských služeb, ačkoliv jsou zapotřebí doma, a kvưli tomu pak celé hospodářství zahálí. ${ }^{53}$ Stížnost obsahovala i poznámku o nemožnosti uzavírat volně sňatek před vysloužením povinných let ve vrchnostenských podnicích, ovšem s výjimkou peněžní výplaty ve výši 8 zlatých vrchnosti a 1 zlatý 30 krejcarů úředníkovi za povolení. ${ }^{54}$ Tato částka $\mathrm{v}$ dané době dle údajů $\mathrm{z}$ řady panství odpovídala zhruba roční mzdě dospělého čeledína. Z této doby (1657) také pochází odpověd' královské komory na stížnost poddaných pardubického panství proti neúměrnému umíst’ování selských dětí do panských služeb, načež komora odpověděla, že , ačkoliv takovou jich žádost dokonce neslušnou z ohledu toho, že by oni poddaní tím prostředkem sobě nějakou svobodu osobovati a z poslušnosti a služebnosti poddaných se vytahovati chtěli; ano i jiných panství poddaní lidé tou cestou postupovati mohli, poznáváme“. V pokračování textu je pak nařízeno k dvorským službám užívat především dospělé sirotky, pokud by se jich nedostávalo, pak mají být do panské služby dávány dospělé děti hospodářů, kteří mají více než jednoho potomka, a to na jeden až tři roky dle potřeby a uvážení. ${ }^{55}$ Tato praxe v podstatě odpovídá zvyklostem popisovaným v německém prostředí po třicetileté válce, kde byly k vrchnostenské službě nuceny děti usedlých i neusedlých poddaných, a to nejčastěji v délce trvání tři let. Rodičům pak mělo být ponecháno jedno dítě jakéhokoliv pohlaví k obstarávání vlastního hospodářství. ${ }^{56}$

H. Morgenstern rozlišuje nucenou práci (službu) do dvou kategorií: 1) robotní službu poddaných sedláků a 2) nucenou práci jiných poddaných, zejména selských dětí, které se pracovně neuplatnily v hospodářství otce. ${ }^{57}$ Námezdní poměr upevňoval poddanství vůči vlastní vrchnosti, jelikož jí poskytoval větší a neomezenější možnost využít pracovní síly v porovnání s robotní povinností. ${ }^{58}$ Typickým př́íkladem uzavírání čeledních smluv ve vrchnostenských službách byly tzv. sirotčí stavuňky, doložené již v 16. století. Každoročně konané (zpravidla v prosinci) přidělování sirotků a později i dalších dětí „živých“ hospodářů do panské služby bylo doprovázeno pořizováním evidence poddanských dětí, následně tato povinnost přešla na všechny poddané. Věk stavěných dětí přitom nebyl přesně dán, nejčastěji se však jednalo o děti starší deseti let. ${ }^{59} \mathrm{~V}$. Urfus v této souvislosti srovnává právní postavení čeledína s placeným robotníkem své vrchnosti, ${ }^{60}$ přičemž konstatuje: „Pro vrchnost je námezdní pracovník zásadně jen placeným nevolníkem. Námezdní poměr

53 Rovněž na panství Točník nebrala vrchnost ohledy na potřeby rodičů dětí umist'ovaných do panské služby, kterým svévolně prodlužovala čelední léta. Viz MAUR, E. Poddaní točnického panství v druhé polovině 17. století. In: MAUR, E. et al. Historik bez hranic. Z dila profesora Eduarda Maura. Pardubice: Univerzita Pardubice, 2017, s. 111-170, zde s. 166.

54 ČECHURA, J. Černínové versus Kysíbelští. Praha: Dokořán, 2003, s. 130.

55 KALOUSEK, J. (ed.). Řády selské a instrukce hospodářské (AČ 23: 1627-1698). Praha: Domestikální fond království Českého, 1906, s. 344, č. 259.

KÄHLER, c. d., s. 3-4.

MORGENSTERN, c. d., s. 42.

URFUS, $c$. d., s. 208.

KROFTA, c. d., s. 203.

URFUS, c. d., s. 208-210. 
je tedy prostředkem, jak rozšśřit, třebas jen dočasně, počet poddaných. "61 Z opačného hlediska a zcela na okraj hodnotí vztah robotní povinnosti a služby v podobě námezdní práce J. Čechura: „Robota se s rozvojem hospodářství po třicetileté válce a při snaze vrchnosti o snížení peněžních výdajů za námezdní práci rozšiŕila měrou vskutku dosud nebývalou.“ Autor přitom poznamenává, že možnost nucené práce, za kterou by vrchnost nemusela platit hotovými penězi, existovala i v podobě tzv. nucené námezdní práce (tedy nucené služby), jejíž odměňování bylo realizováno v naturální podobě produkty vrchnostenských dvorů (sýry, máslo apod.). ${ }^{62}$ Snahu pobělohorského velkostatku nahradit námezdní práci neplacenou robotou zmiňuje rovněž E. Maur, který zásadní zlom tohoto vývoje klade do období 70 . a 80 . let 17 . století, kdy začaly být robotní povinnosti ze strany vrchností vymáhány v maximální míře. ${ }^{63}$ Zajímavou otázkou pak také zůstává reálný rozdíl mezi nucenou námezdní prací a honorovanou robotou, které od sebe nelze zcela jasně odlišit a které byly typické především pro nižší sociální vrstvy. ${ }^{64}$

Povinná služba sirotků i jiných poddaných u vrchnosti neměla být prodlužována déle než zmíněné třri roky. ${ }^{65}$ Přesto si např. v Dolních Rakousech sedláci opakovaně stěžovali, že jejich děti musí vrchnosti sloužit pět nebo šest let, někde byla nařízena dokonce sedmiletá nucená služba. Takové zprávy máme rovněž z některých českých panství. ${ }^{66}$ Přese všechno měli sloužící nárok na plat a deputát (jídlo, ošacení, ubytování), byt' existuje mnoho zpráv, že se jednalo o těžko vymahatelné záležitosti. ${ }^{67}$ Právě výrazně nižší mzda než v př́ípadě služby dobrovolné měla být typickým znakem nucené čelední služby. ${ }^{68}$ Poddaní se na některých panstvích měli možnost z povinné služby vykoupit často dosti vysokými poplatky. ${ }^{69}$

Jedním z aspektů definujících povinnou službu byl také vyšší průměrný věk sloužících vybíraných do dvorů a dalších vrchnostenských podniků. Důležitým hlediskem byla fyzická zdatnost jedinců, kterou práce ve dvorech vyžadovala. ${ }^{70}$ Věk většiny dvorské čeledi se pohyboval mezi 20 a 24 lety. ${ }^{71}$ Zastoupení dvorských sloužících dle pohlaví záviselo na způsobu hospodaření daného velkostatku. Práce s dvorským potahem předpokládala

\footnotetext{
61 Tamtéž, s. 200.

62 ČECHURA, c. d., s. 32-33, 135.

63 MAUR, Český komorní velkostatek, s. 53-54.

64 Tamtéž, s. 110.

65 Na konci 17. století nařídila česká komora pod vlivem populačních ztrát zkrátit povinnou službu sirotků ze tří na dva roky. Mělo tím být zabráněno i zvyšujícímu se trendu zbíhání čeledi. Tamtéž, s. 122.

66 Tamtéž, s. 122.

67 MORGENSTERN, c. d., s. 58-59; KLÍMA, Manufakturní období, s. 40. Čeled’ byla sjednávána zpravidla na rok, ale většina čeledínů pracovala ve vrchnostenských službách řadu let. Viz MÍKA, $c$. $d$., s. 150. Dle nařízení z roku 1615 nesměla být na komorních panstvích čeled' nucena k práci na dobu delší než tři roky. Viz KROFTA, c. d., s. 106 a násl.

68 KÄHLER, $c . d$. , s. 3.

69 KLÍMA, Manufakturni obdobi, s. 41; KROFTA, c. d., s. 203; PRAŽÁKOVÁ SELIGOVÁ, M. Život poddaných v 18. stoleti: osud, nebo volba? K demografickým, hospodářským, sociálním a rodinným aspektům života venkovských poddaných na panství Horni Police. Praha: Togga, 2015, s. 277-278; MAUR, Český komorni velkostatek, s. 123.

70 MAUR, Český komorní velkostatek, s. 123.

71 PRAŽÁKOVÁ SELIGOVÁ, $c$. d., s. 280; SLÁDEK, M. Čeled' na třeboňských panstvích v polovině 17. století. Historická demografie, 1987, č. 11, s. 51-96, zde s. 56, 69.
} 
více zaměstnaných mužů, tam, kde byla dvorská pole obdělávána poddanskými potahy (v rámci robotních povinností), převažovalo spíše ženské osazenstvo. ${ }^{72}$

Jasné zakotvení povinné služby v českém právním systému bylo definitivně stvrzeno čeledním řádem Marie Terezie z roku 1765, podle kterého měla pozemková vrchnost možnost odvolat poddaného z aktuálně sjednané služby z důvodu vlastní potřeby, přičemž rodiče nově nemohli rozhodovat o tom, zda své dítě v rámci hospodářství potřebují či nikoliv. To př́islušelo vrchnostenským úředníkům prostřednictvím každoročního stavění sirotků a čeledi. Povinnost poddaných dávat své děti do panských služeb skončila $\mathrm{k} 1$. listopadu 1781, kdy bylo zrušeno nevolnictví. Tento stav byl následně potvrzen josefínským řádem pro venkovskou čeládku z roku $1782 .{ }^{73}$ Povinná čelední léta v délce maximálně tří let tak zůstala $\mathrm{v}$ platnosti jen pro poddanské sirotky.

V české historiografii nebyl v minulosti názor na (povinnou) službu u vrchnosti vždy jednotný. Např́klad A. Míka při hodnocení pozitiv a negativ zejména ve srovnání s nádenickou prací tvrdil, že ,výhody povyšovaly vrchnostenskou čeled' nad ostatní námezdně pracující“. Vycházel přitom z předpokladu jistoty celoročního zaměstnání a plného zaopatření ve formě mzdy, ale především naturální odměny a ubytování, což nádeníkům nepř́íslušelo. ${ }^{74}$

Poddaní ve snaze ochránit vlastní děti před službou u vrchnosti využívali různé strategie, at' už šlo o zapírání či ukrývání dětí, zdůvodňování jejich potřeby pro vlastní hospodářství i předstírání jejich nemoci. Někdy je rodiče posílali do služby na cizí panství bez povolení vrchnosti (např́íklad k příbuzným), často mladí lidé zbíhali sami od sebe, bud' př́mo z panské služby, nebo aby se vstupu do ní případně vyhnuli. ${ }^{75}$

Absolvováním nucené vrchnostenské služby neboli tzv. povinných let bylo často podmíněno udělení vrchnostenského souhlasu k sňatku poddaného. Některé skupiny osob však mohly být povinné služby zproštěny, například děti cechovních řemeslníků, jako tomu bylo např́iklad na Hornopolicku v severních Čechách. ${ }^{76}$

\section{Čelední právo ve středoevropském kontextu}

Vývoj českého a moravského čeledního práva, které od středověku tvoří nedílnou součást práva pracovního, je na rozdíl od většiny zemí ve středoevropském prostoru možné hodnotit jako vcelku jasný a přímočarý. $\mathrm{V}$ řadě př́ípadů jsme schopni doložit kontinuitu jednotlivých ustanovení českého čeledního práva od 14. či 15. století v podstatě až do doby kodifikace občanského práva na počátku 19. století. Důvodem tohoto stavu je především relativně brzká kodifikace čeledních norem v rámci práva městského i zemského, potažmo partikulárních právních úprav na úrovni jednotlivých pozemkových vrchností. Důležitými faktory oné přehlednosti a přímočarosti jsou zejména relativní územní celistvost Čech a Moravy bez historicky výraznějších mocenských vlivů cizích států, politická síla zemských orgánů až do roku 1620, tedy v době, kdy dochází ke kodifikaci všech

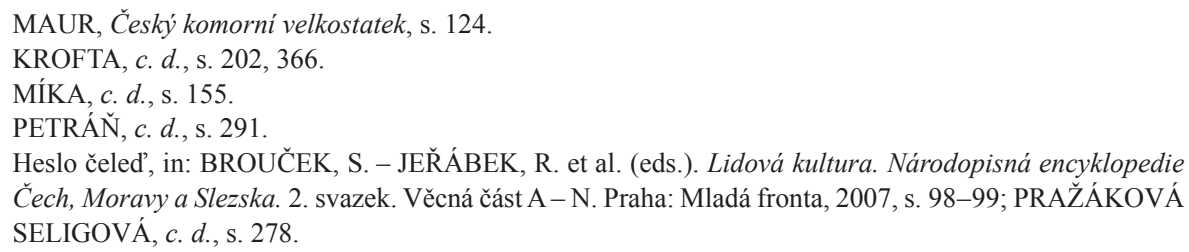


důležitých norem pracovního práva (ve vztahu k čeledi), a v neposlední řadě propracovanost a životaschopnost těchto právních norem nebo jejich částí, které vydržely v platnosti často mnoho desetiletí. ${ }^{77}$ Přesto jsou možnosti komparace právního vývoje v jednotlivých historických zemích (tedy i mezi Čechami a Moravou) značně omezené, což je dáno specifickým vývojem jejich zemského i městského práva.

Tato situace je mnohem markantnější v německých zemích, kde teritoriální roztř́ǐštěnost území a odlišný charakter právních poměrů neumožňují zcela definovat společné rysy či vývojové tendence čeledního práva, ${ }^{78}$ byt' tradice studia sociálních a zejména právních poměrů sloužících na rozdíl od tuzemské historické a právní vědy sahá v Německu až do poslední třetiny 19. století, od kdy je intenzivně rozvíjena v podstatě až do současnosti. ${ }^{79}$ Jak poznamenává R. Schröder, v každém německém teritoriu se od raného novověku najdou stovky, ne-li tisíce norem upravujících práva sloužících, at' už jde o „zákony“, policejní a čelední řády atd., které ztěžují interpretaci jednotného čeledního práva. ${ }^{80}$

Po stránce chronologické lze tuzemský vývoj s německým srovnávat pouze v omezené míře už jen z důvodu nepoměru v množství a druhu norem, které jsou pro německé oblasti běžné, ale v Čechách chybí (např. silný odkaz na protestantskou literaturu a z ní vycházející žánr tzv. Hausväterliteratur, která v 16.-18. století sloužila jako důležitý normativní pramen), ale rovněž z hlediska časově neodpovídajícího průběhu kodifikace různých typů práva oproti Čechám. Jako př́klad uved’me kodifikaci civilního práva, která v Bavorsku proběhla na základě Codex Maximilianeus Bavaricus Civilis již v roce 1756, nebo v Prusku vydáním Všeobecného zemského práva (Das Allgemeine Landrecht) z roku 1794 představujícího přechod od stavovského k občanskému právu. Na druhou stranu osvícenské reformy spojené v rakouské monarchii především se zrušením nevolnictví v roce 1781 a na to navázanými změnami čeledního práva v roce následujícím (zejména zrušení povinné služby u vrchností) proběhly v Prusku až téměř o dvacet let později na základě čeledního řádu z 8. listopadu $1810 .{ }^{81}$

Rovněž z hlediska obsahového vycházelo čelední právo německé z odlišného vývoje než české. Od 16. století je v německých zemích patrný trend spojování privátních a trestněprávních aspektů se správně-právními a policejními předpisy, které výrazně rozšiřovaly pozdně středověká nařízení týkající se čeledního práva. Už jen jeho definice současnými kategoriemi je značně složitá, jelikož dnes bychom části jednotlivých norem hledali v okruhu práv soukromého, trestního i veřejného. ${ }^{82} \mathrm{~V}$ obecné rovině lze konstatovat, že

77 Nutno podotknout, že tento stav byl podpořen i mírou přežívajícího zvykového práva, které v případě úpravy čeledních poměrů tvořilo v Čechách důležitou součást právního prostředí ještě v 18. století.

78 DÜRR, ,,Der Dienstbothe ist kein Tagelöhner... “; SCHRÖDER, Gesinderecht im 18. Jahrhundert.

79 Výběrem KOLLMANN, P. Geschichte und Statistik des Gesindewesens in Deutschland. Jahrbücher für Nationalökonomie und Statistik, 1868, Jhrg. 10, s. 237-301; WUTTKE, R. Gesindeordnungen und Gesindezwangsdienst in Sachsen bis zum Jahre 1835. Leipzig: Duncker \& Humblot, 1893; KÄHLER, c. d.; KÖNNECKE, O. Rechtsgeschichte des Gesindes in West- und Süddeutschland. Marburg: Elwert, 1912; STOLZ, O. Rechtsgeschichte des Bauernstandes und der Landwirtschaft in Tirol und Vorarlberg. Bozen: Ferrari-Auer, 1949; SCHRÖDER, R. Das Gesinde war immer frech und unverschämt. Gesinde und Gesinderecht vornehmlich im 18. Jahrhundert. Frankfurt a. M.: Keip, 1992; WEBER, M. Die schlesischen Polizei- und Landesordnungen der Frühen Neuzeit. Köln - Weimar - Wien: Böhlau, 1996; DÜRR, ,Der Dienstbothe ist kein Tagelöhner... “.

80 SCHRÖDER, Gesinderecht im 18. Jahrhundert, s. 28-33.

81 KÄHLER, c. d., s. 7.

82 DÜRR, ,,Der Dienstbothe ist kein Tagelöhner... “, s. 117-118. 
české a německé čelední právo bylo vystavěno na odlišných principech, kdy to, co direktivně nařizovala ustanovení českých řádů, bud' představovalo samozřejmou a historicky danou součást předpisů německých, nebo v těchto naopak obsaženo vůbec nebylo. Př́kladem budiž povinný slib věrnosti pozemkové vrchnosti, který musel dle würtemberského zemského zřízení z roku 1536 učinit každý čeledín nejpozději do osmi dní od nástupu do služby. Takovéto ustanovení v rámci českého zemského práva nikdy uzákoněno nebylo. Na druhou stranu český čelední řád z roku 1765 stanovoval povinnost sloužícího při nástupu do služby odevzdat zaměstnavateli veškeré své ošacení a osobní věci (truhlici) jako preventivní opatření před případným zběhnutím, ${ }^{83} \mathrm{v}$ německém prostředí naopak představoval tento akt tradiční symbolické stvrzení nástupu čeledína do služby u nového hospodáře (uložení truhlice a oblečení v domě pána). ${ }^{84}$ Stejně tak bychom mohli zmínit roli dohazovačů a zprostředkovatelů práce, jejichž existence byla v německých zemích samozřejmou součástí procesu najímání námezdních pracovníků v městském prostředí, zatímco v Čechách byly tyto osoby v 18 . století stavěny mimo zákon. ${ }^{85}$

Účel vydávání čeledních předpisů v českých a německých zemích se rovněž lišil. Zatímco v Čechách šlo především o posílení práv vrchností nad sloužícími, jejichž možnosti obrany proti disciplinárním pravomocem zaměstnavatele se postupem doby zmenšovaly, přičemž vyvrcholením tohoto trendu byl již zmiňovaný čelední řád z roku 1765, v německém prostředí nebyla situace natolik přímočará, byt' obdobný trend tu je jasně patrný také. Od 16. století zde důležitou úlohu hrály mzdové předpisy či řády (Taxordnungen), které byly v průběhu staletí vydávány ve velkém počtu, často opakovány a zpř́ísňovány. Na jednu stranu musely reagovat na růst cen a nedostatek pracovních sil postupným zvyšováním mezd především v průběhu 18. století, na druhou stranu se snažily kontrolovat a omezovat podmínky v čeledních smlouvách, které měly minimalizovat riziko zbíhání poddaných z důvodu lepší mzdové nabídky. ${ }^{86}$ České čelední předpisy naproti tomu na stanovování maximálních mezd rezignovaly poměrně záhy, již v polovině 16 . století. Na celozemské úrovni prvními ${ }^{87}$ a v podstatě posledními normami, kde se mzdové taxy objevují, jsou čelední řády z let 1547 a 1549, přičemž ani ony nebyly schopné určit jednotnou hranici př́ijmů některých kategorií námezdně pracujících osob. V důsledku nedodržování mzdových nařízení proto bylo od této reglementace upuštěno zcela, přičemž novější předpisy už prakticky obsahují pouze formulaci o „mzdách v místě obvyklých“, v jejímž duchu nemělo docházet $\mathrm{k}$ přeplácení čeledi.

I přes jisté obsahové rozdíly lze v českém a německém čeledním právu nalézt celou řadu v podstatě shodných prvků, které jsou v obou systémech rozpracovány s odlišným akcentem. Podobně vyznívaly především základní povinnosti sloužících (nutnost dosloužit

83 Viz $§ 15$ hlavy VI. čeledního řádu pro Čechy z roku 1765; dále DÜRR, ,,Der Dienstbothe ist kein Tagelöhner... ", s. 126.

84 DÜRR, „Der Dienstbothe ist kein Tagelöhner... “, s. 117, 128.

85 Viz § 16 hlavy II. čeledního řádu pro Čechy z roku 1765.

86 DÜRR, „,Der Dienstbothe ist kein Tagelöhner... “, s. 121; SCHRÖDER, Gesinderecht im 18. Jahrhundert, s. 33-35.

87 Mzdové tarify stanovující maximální mzdy pro námezdní pracovníky známe v evropském prostoru již z poloviny 14. století, zejména v souvislosti s morovými epidemiemi, které vlivem zvýšené úmrtnosti způsobily nedostatek pracovních sil, které byly v důsledku toho značně přepláceny. V Čechách nejstarší datovatelné mzdové nařízení pochází z 80. let 14. století z Chebu. Více viz MAUR, E. Morová epidemie roku 1380 v Čechách. Historická demografie, 1986, č. 10, s. 37-71, zde s. 47. 
smluvenou dobu, požadavek na poslušnost, věrnost, pracovitost čeledi atd.), ale i práva (nárok na mzdu, stravu a ošacení), podmínky nástupu (v německých zemích možné čtyři termíny, v Čechách pouze jeden) a ukončení čeledního poměru (výpovědní lhůta, závdavek ad.), délka služby, která byla shodně stanovena na jeden rok, ale také tresty za prŕípadné provinění (tělesné tresty častější než pokuty). ${ }^{88}$

Co se týče obsahového vývoje norem čeledního práva, méně už časového, vypadala podobně situace rovněž v Polsku, kde však došlo k jednotné právní úpravě venkovské námezdní práce na státní úrovni až v první třetině 19 . století (1817 a 1823). ${ }^{89}$ Tyto normy navíc stály na úrovni kodifikací českého čeledního práva z doby tereziánské (policejní čelední řády). I zde ovšem najdeme řadu paralel s prvky českého i německého zákonodárství. Specializované předpisy upravující námezdní práci začaly v Polsku vznikat až počátkem 18. století, do té doby existovalo jen minimum norem. Např́klad v Gdaňsku bylo vydáno v průběhu 18. století několik výnosů, které je možné považovat za první skutečnou pracovní legislativu týkající se čeledních poměrů. Nejstarší a zároveň nejdůležitější z nich z roku 1705 například nařizoval, že sloužící mají nosit méně okázalé oděvy, zaváděl povinnost obracet se v př́ípadě najímání do služby na specializované agentury (podobně jako v Německu), které byly oficiálními zprostředkovateli práce uznanými městskými úřady, ale také obsahoval reglementaci mezd čeledi, kdy stanovené mzdové taxy bylo zakázáno překračovat. Nařízení dále reflektovalo trestněprávní aspekty zahrnující, mimo jiné, povolení tělesných trestů, které ovšem neměly způsobovat vážná zranění, natož pak trvalé následky. Po dokončení služby měl čeledín, stejně jako v Čechách, obdržet vysvědčení obsahující objektivní vyjádření o kvalitě jeho práce..$^{90}$

Čelední právo rakouské se nacházelo nejblíže tomu českému, což logicky vychází ze společného fungování českých zemí v jednom státním útvaru s rakouskými dědičnými zeměmi, resp. od roku 1526 pod vládou jednoho panovníka. H. Morgenstern vymezil v rámci rakouského čeledního práva čtyři zřetelné epochy, které v podstatě kopírují český právní vývoj v této oblasti. Jde o (1) období vrcholného a pozdního středověku (13.-14. století), charakteristické stabilizací sociální struktury společnosti, kdy se v právních pramenech začalo uvažovat o kategorii ,čeledi“ v užším slova smyslu, tedy jako o svobodných osobách, které se najímaly do smluvní služby pro venkovské a domácí práce na určitý delší čas, a to tím způsobem, že vstoupily do domácnosti zaměstnavatele (Hausverband). Již v tomto období se formovala pevná pravidla pro zaměstnávání osob sloužících, včetně ustanovení stran najímání a ukončování čeledního poměru (už tehdy bylo možné zrušit pracovní poměr ze šesti důvodů na straně zaměstnance i zaměstnavatele), práv a povinností sloužícího i pána apod., byt' k jednotné kodifikaci zatím nedošlo. ${ }^{91}$

Další epocha (2) byla vymezena počátkem raného novověku (15. století) a obdobím vlády Marie Terezie, přičemž ji lze charakterizovat jako dobu státních policejních regulací. Obecným základem čeledního práva se v tomto ohledu stal říšský policejní ráád pro Augsburg z roku 1530, na který navazovala řada policejních norem rakouských. Nejstarší rakouskou právní úpravou čeledních záležitostí byl policejní řád Ferdinanda I. z 1. dubna 1527 pro Vnitřní Rakousy, Görz a Gradisku, po něm následovaly další z let 1542 a 1552.

88 DÜRR, „, Der Dienstbothe ist kein Tagelöhner... “, s. 121-125.

89 Blíže k právnímu postavení sloužících v Polsku viz KUKLO - KAMECKA, $c$. $d$.

90 Tamtéž, s. 125-129, 131.

91 MORGENSTERN, c. d., s. 5-8. 
Jmenovat ale můžeme i další, např. pro Tyrolsko z roku 1573 či pro Salzburg z roku 1629. Kromě zemského zákonodárství, kde výsadní postavení zaujímaly Čechy se svým Vladislavským zrrízením zemským z roku 1500, vycházely i speciální mandáty a čelední řády, opět však pouze pro určené historické země. Nejvíce jich bylo vydáno opět ve Vnitřních a Dolních Rakousech (1550, 1565 mandáty, 1568 generální patent), vrchol čeledního zákonodárství ztělesňoval Dienstbotenordnung Leopolda I. z roku 1688. Stejně jako v Čechách je i v rakouských zemích toto období typické vydáváním celé řady poddanských a čeledních řádů a statut na úrovni jednotlivých panství, potažmo vrchností, což reprezentuje nejnižší úroveň zákonodárné moci v oblasti poddanského práva. ${ }^{92}$

Následující období (3) představovalo vládu Josefa II. a Františka I. do konce 18. století, charakteristickou zásadními osvícenskými reformami na poli poddanského práva (zejm. zrušení nevolnictví), poslední epochou pak byla éra 19. století (4) typická kodifikací občanského práva a rozkladem robotního velkostatku. Rakouské právo těchto dvou období již bylo natolik svázáno s právem českým, že není třeba uvádět konkrétní evoluční paralely.

Jak jsme naznačili výše, vývojové nuance i rozdíly zásadnějšího rázu v právních systémech jednotlivých zemí nelze ignorovat. Co však bylo charakteristické pro čelední právo napříč evropským prostorem bez rozdílu? Jak píše R. Schröder, jednalo se o tu část předprůmyslového pracovního práva, ve které mohlo být smluvní plnění legálně vynucováno tělesným násilím a za pomoci policie. Hlavním účelem čeledních řádů bylo zákonné ovlivnění pracovního trhu ve snaze po uspokojení všeobecné poptávky po levné pracovní síle, byt' jejich dosah a efektivitu lze $\mathrm{z}$ dnešního pohledu jen velmi obtížně hodnotit. ${ }^{93}$

\section{Závěrem}

Jak jsme ukázali v předchozím výkladu, problematika pracovního práva v období raného novověku není záležitostí úplně jednoduchou, naopak se jedná o značně komplikovanou a mnohovrstevnatou část soukromého práva (alespoň převážně), která byla utvářena a rozvíjena hned na několika úrovních.

Pokud celou věc značně zjednodušíme, můžeme raně novověké čelední právo rozdělit dle působnosti na městské a poddanské, jejich společné jádro tvořilo právo zvykové, kodifikované v obou prŕípadech v průběhu 16. století. Přesto některé části čeledního práva zůstávaly v rovině obyčejů až do 18 . století (např. služba osob stavovského původu u šlechtických zaměstnavatelů, oficiantů ad.).

Normativní základ (ve vztahu ke kategorii sloužících), který se ustálil v průběhu 16. století, byl v následujících obdobích rozvíjen či potlačován vlivem mocenských ambicí habsburského státu, v 17. a 18. století doprovázených utužováním poddanské závislosti na pozemkové vrchnosti, centralizačními snahami a rozvojem policejních nařízení. K jistému uvolnění situace došlo až postupným pronikáním osvícenských myšlenek do rané josefínské legislativy upravující poměry nižších vrstev tehdejší společnosti. Tento proces pak vyvrcholil zrušením nevolnictví v roce 1781, což vedlo k rozvolnění osobních svazků poddaného s dědičnou vrchností a přinášelo poddaným nové možnosti v podobě volného pohybu, uzavírání sňatků či přístupu ke vzdělání. To však neznamenalo, že by až do poloviny 19. století nepřestal být nejcharakterističtějším prvkem čelední služby osobní

92 MORGENSTERN, c. d., s. 5, 12-16.

93 SCHRÖDER, Gesinderecht im 18. Jahrhundert, s. 15, 37. 
svazek sloužícího se zaměstnavatelem, který ve svých rukou držel veškerou disciplinární pravomoc nad osobami v dlouhodobém námezdním pracovním poměru. Jak také vyplývá z rozboru českých i zahraničních raně novověkých právních norem, přičlenění čeledi do okruhu zaměstnavatelovy rodiny je v tomto období jen těžko zpochybnitelné.

Shrneme-li pak hlavní vývojové tendence českého raně novověkého čeledního práva, je zcela zřejmé, že jeho pevným základem se stal čelední řád přijatý na zemském sněmu v roce 1547 , který představoval konsenzus tehdejší stavovské reprezentace s přihlédnutím ke zvláštním potřebám a podmínkám jednotlivých českých krajů. Podstatná část ustanovení zmíněného řádu byla záhy implementována do zemského zřízení z roku 1564, odkud přšsla i do Obnoveného zrrízení zemského (1627), kde formálně zůstala v platnosti až do první poloviny 19. století, nicméně fakticky byla zcela překryta dikcí čeledních řádů tereziánského a josefínského období $(1765,1782)$.

V krátkém exkurzu jsme se zaměřili také na problematiku tzv. povinné či nucené služby, která se dotýkala v podstatě výhradně venkovského prostoru a vycházela z tradičního práva pozemkových vrchností na neomezené nakládání se svými poddanými. Její potřeba se projevovala již od 16. století a byla spojena s rozvojem panského režijního hospodaření, které bylo závislé na prrísunu značného množství levné pracovní síly pro zabezpečení fungování vrchnostenských podniků, především poplužních dvorů. Zatímco na některých panstvích využívala vrchnost institutu povinné služby velmi hojně a máme doklady o čeledi nucené sloužit na panském po dobu pěti i šesti let, existovaly naopak lokality, kde nucená služba př́liš nezdomácněla. Přestože měla tato forma dlouhodobého námezdního poměru svá specifika týkající se například věku či genderové stratifikace sloužících, dotkla se shodně všech oblastí ve středoevropském prostoru, přičemž, jak jsme uvedli, v českých a rakouských zemích jí byl učiněn konec (kromě povinných sirotčích let) až v roce 1781 v souvislosti s vydáním patentu o zrušení nevolnictví.

I přes konstatovaný diametrální rozdíl právních systémů sousedních zemí můžeme v raně novověkém čeledním právu pozorovat jisté vývojové i obsahové paralely napříc širším územím střední Evropy, vycházející z nejméně jednoho společného cíle všech normativů, kterým byla regulace pracovního trhu vedoucí k uspokojení zpravidla výrazné poptávky po často nedostatkové levné pracovní síle. Přese všechny rozdíly obsahovala čelední legislativa jednotlivých zemí podobná či shodná ustanovení týkající se především povinností zaměstnance, podmínek uzavírání a ukončování pracovního poměru či vyplácení mzdy. Otázkou ovšem zůstává reálný dosah většiny právních norem týkajících se pracovního práva v období raného novověku. Na základě prozatím nečetných výzkumů na toto téma se však zdá, že rozpor mezi zákonnými předpisy a jejich faktickým dodržováním či vymáháním byl v případě námezdní práce poměrně velký. 